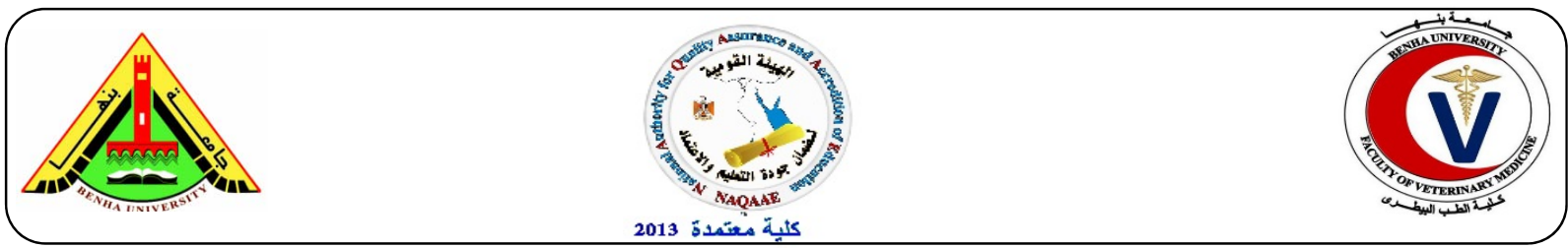

\title{
Improvement the Shelf Life of Tilapia Fillets Stored at Chilling Condition
}

\author{
Thabet M. Gerges ${ }^{1}$ Amany Selim² and Mai Osman ${ }^{3}$ \\ ${ }^{1}$ Animal Health Research Institute (Benha Branch-Food Control Department). ${ }^{2}$ Animal Health Research Institute \\ (Benha Branch Microbiology Department). ${ }^{3}$ Animal Health Research Institute (Benha Branch-Biochemistry \\ Department)
}

\section{A B S T R A C T}

The main purpose of this investigation was to study the effect of immersing fillets of Nile Tilapia (Orechromis niloticus) in $1 \%$ acetic acid and storage under standard conditions $\left(80 \% \mathrm{CO}_{2}: 20 \% \mathrm{~N}_{2}\right)$ at a temperature of $2^{\circ} \mathrm{C}$ on their shelf life. Fillets samples were divided into four groups, Group 1 (G1): the fillets immersed in sterilized distilled water for 2 minutes and packaged in Polyamide/ Polyethylene (PA/PE) bags. Group 2 (G2): the fillets immersed in sterilized distilled water and stored under standard conditions. Group 3 (G3): the fillets immersed in 1\% acetic acid for 2 minutes and packaged in PA/PE bags. Group $4(\mathrm{G} 4)$ : the fillets immersed in 1\% acetic acid and stored under standard conditions. All samples were stored at a temperature of $2^{\circ} \mathrm{C}$ for 21 days and analyzed at the beginning of the experiment and after 7,14 and 21 days of storage. Results of the study showed that the organoleptic properties of tilapia fillets dropped by the extension of the cold storage time to 21 days. The average values of Thiobarbituric acid-reactive substances (TBARS) in the G1, G2, G3 and G4 are $9.23,2.56,8.07$ and 0.98 at day 21 of the cold storage at a temperature of $2{ }^{\circ} \mathrm{C}$, respectively. Tilapia fillets kept under $\mathrm{CO}_{2}$-enriched atmosphere had lower total volatile base nitrogen (TVB-N) than those stored in air where the average values were $19.9,15.93,18.97,15.93 \mathrm{mg} / 100 \mathrm{~g}$ in G1, G2, G3 and G4, respectively at the end of the storage period. The results also showed that the total viable count (TVC) remained at permitted in G4 as the average number was $6.14 \pm 0.05 \times 10^{3}$ after 21 days of storage at a temperature of $2{ }^{\circ} \mathrm{C}$, while in G1, G2 and G3 were $7.53 \pm 0.06 \times 10^{6}, 7.63$ $\pm 0.11 \times 10^{5}$ and $5.30 \pm 0.09 \times 10^{6}$ respectively. Thus, the results indicated that the tilapia fillet immersion in $1 \%$ acetic acid and storage under standard conditions that have been applied in our study contributed to the extension of the validity period for tilapia fillet for a longer period of cold storage of up to 21 days.

Keywords: Nile tilapia, fillets immersion, validity period, TBARS.

(http://www.bvmj.bu.edu.eg)

(BVMJ-31(2): 45-55, 2016)

\section{INTRODUCTION}

Fish is one of the most highly perishable foods and its shelf life is limited in the presence of normal air due to the chemical effects of atmospheric oxygen and the growth of aerobic spoilage microorganisms. Freshness is one of the most important aspects of fish because consumers have a strong tendency to select very fresh fish (Luten and Martinsdóttir, 1997; Ross, 2000). Typical shelf life under chilled storage conditions ranges from 6 to 20 days (Cyprian et al., 2008; Martinsdóttir et al., 2001) depending on species, harvest location and season, and can result in heavy economic loss (Reddy et al., 1995; Sivertsvik et al., 2002). Extending fish shelf life is greatly advantageous to industry, as it reduces losses during product distribution and display, which may result in marketing improvements for fresh products and in a regular supply at reasonable prices (Lioutas, 1988). Shelf life of fishery products is usually limited by microbial activities that are influenced most importantly by storage temperature (Huss, 1994; Simpson et al., 2003). Bacterial changes are considered the most important cause of fish spoilage (Gram and Dalgaard, 2002). This is because spoilage is often a result of off-odors and off-flavors caused by bacterial metabolism (Gram et al., 1990). Modification of the atmosphere within the package by decreasing the oxygen concentration, while increasing the content of carbon dioxide and nitrogen, has been shown to significantly prolong the shelf life of perishable food products at chill temperatures (Parry, 1993; Reddy et al., 1995; Siah and Mohd Ariff, 2002). The shelf life of fish products in Modified atmosphere packaging (MAP) can be extended, depending on raw materials, temperature, gas mixtures and packaging materials (Farber, 1991). MAP of fishery products has been shown to inhibit the normal spoilage flora and increase shelf life 
significantly at cool temperatures (Sivertsvik et al., 2002). The application of this technology to foods has become increasingly more available in recent years as food manufacturers have attempted to meet consumer demands (Sveinsdottir et al., 2010). The techniques for modified atmosphere packed products involve the use of several gases, such as $\mathrm{CO}_{2}, \mathrm{~N}_{2}$ and $\mathrm{O}_{2}$. Carbon dioxide, whether alone or associated with other gases, being the most effective and common amongst them. Such an effect is influenced by the $\mathrm{CO}_{2}$ concentration, initial bacterial population, storage temperature and product type (Reddy et al., 1992). Also, Reddy et al. (1994) evaluated the effect of modified atmospheres $\left(75 \% \quad \mathrm{CO}_{2} / 25 \% \quad \mathrm{~N}_{2} ; 50 \%\right.$ $\mathrm{CO}_{2} / 50 \% \mathrm{~N}_{2} ; 25 \% \mathrm{CO}_{2} / 75 \% \mathrm{~N}_{2}$ ) on the shelf life of tilapia (Tilapia spp.) fillets packed in high barrier film at $4^{\circ} \mathrm{C}$. The authors observed that tilapia fillets packed in $75 \% \mathrm{CO}_{2} / 25 \% \mathrm{~N}_{2}$ showed an increased shelf life of more than 25 days, presenting acceptable sensory characteristics. Duun and Rustad (2008) reported ice chilled salmon fillets in combination with MAP to have maintained good quality with negligible microbial growth for more than 17 days based on both sensory and microbial analyses. According to Marel et al. (1988), the superficial application of organic acids is used for meat decontamination, aiming mainly at reducing the deteriorating and pathogenic microorganisms naturally found in food. Some studies on the possibility of combining MAP with preservatives to preserve fresh fish have been conducted, in order to develop fish products presenting better quality and longer shelf life. Acetic acid and its salts are very efficient and widely used as acidulating agents and preservatives for food. The presence of $1-2 \%$ of non-dissociated acid in meat, fish or vegetable products is generally sufficient for bacterial inhibition, as long as good hygiene practices are observed (Pardi et al., 1994). Acetic acid diluted to $0.5 \%$ on catfish fillets would be suitable for prolonging shelf life and appealing to consumers. Acetic acid as a natural antimicrobial product can improve the shelf life and safety of food products providing acceptable sensory quality at an affordable price and reducing economic lost due to spoiled catfish and other food products (Lingham et al., 2012).

The purpose of this experiment is to assess the effect of MAP and the efficacy of acetic acid, when used in conjunction with $80 \% \quad \mathrm{CO}_{2}: 20 \% \mathrm{~N}_{2}$ atmosphere to extend the chilling storage life of fresh tilapia fillets. Quality attributes were assessed by different methods including chemical, microbiological and sensory evaluation.

\section{MATERIALS AND METHODS}

\subsection{Fish preparation}

Forty tilapia fish weighing between 450 and 500 $\mathrm{g}$ were harvested and transported iced to laboratory within three hours. The fish were gutted, skinned, filleted, and divided into four batches: Group 1 (G1): the fillets immersed in sterilized distilled water for 2 minutes at room temperature, then laid on racks for 2 minutes to drain the solution and were packaged in Polyamide/ Polyethylene (PA/PE) bags and stored at $2^{\circ} \mathrm{C}$ for 21 days. Group 2 (G2): the fillets were immersed in sterilized distilled water under the same conditions in (G1), and then laid on racks for 2 minutes to drain the solution. The fillets were stored in gas-tight plastic containers. A mixture of liquefied $\mathrm{CO}_{2}$ and $\mathrm{N}_{2}$ was accomplished using Oxoid's Atmosphere Generation System (AGS). The storage conditions were as follows: temperature $2{ }^{\circ} \mathrm{C}$, concentration of gaseous $\mathrm{CO}_{2}(80 \%)$, and concentration of $\mathrm{N}_{2}(20 \%)$ for 21 days. Group 3 (G3): the fillets underwent chemical treatment by immersion in $1 \%$ acetic acid at the proportion of $1.2: 1$, that is, $1.2 \mathrm{~kg}$ of fish per 1 liter of solution, for 2 minutes at room temperature. The fillets laid on racks for 2 minutes to drain the solution and were packaged in Polyamide/ Polyethylene (PA/PE) bags and stored at $2^{\circ} \mathrm{C}$ for 21 days. Group 4 (G4): the fillets underwent chemical treatment by immersion in $1 \%$ acetic acid as the same in (G3). The fillets were stored in gas-tight plastic containers. A mixture of liquefied $\mathrm{CO}_{2}$ and $\mathrm{N}_{2}$ was accomplished using Oxoid's Atmosphere Generation System (AGS). The storage conditions were as follows: temperature $2{ }^{\circ} \mathrm{C}$, concentration of gaseous $\mathrm{CO}_{2}(80 \%)$, and concentration of $\mathrm{N}_{2}$ (20\%) for 21 days.

The experiment was repeated in triplicate. All previous groups of samples were undergone the following analysis at day 1 and every 7 days:

\subsection{Chemical analyses}

Total volatile base nitrogen (TVB-N) was determined by protein precipitation using trichloroacetic acid (TCA) and evaluation of the total volatile base nitrogen in the TCA extract using the Micro Kjeldhal method, according to Ang (1988). Thiobarbituric acid reactive substances (TBARS) was determined by the precipitation of proteins associated with lipids and phospholipids. The spectrophotometer reading was taken at $535 \mathrm{~nm}$, using a 7.8 conversion factor to transform $\mathrm{mg}$ of malondialdehyde to $\mathrm{kg}$ of food, according to Schmedes and Holmer (1989). $\mathrm{pH}$ was determined by means of a Digimed digital potentiometer, using $5 \mathrm{~g}$ of muscle homogenized with $45 \mathrm{ml}$ of $\mathrm{CO}_{2}$ free distilled water (Lim, 1987). 


\subsection{Microbiological analysis}

Total viable count (TVC): Total viable microbial count on the fillets were determined using the pour plate method according to Maturin and Peeler (2001). Duplicate samples (about $10 \mathrm{~g}$ ) were taken from each fillet at predetermined intervals. Samples were placed in a sterile stomacher bag and homogenized with $90 \mathrm{ml}$ Ringer's solution in the Seward Stomacher (400 Lab Blender) to give $10^{-1}$ dilution. Further 10 -fold serial dilutions were made as required using the same diluent. One $\mathrm{ml}$ of appropriate dilutions was pipetted into two plates and molten standard plate count agar (cooled to $42-45^{\circ} \mathrm{C}$ ) was then poured in. Plates were incubated at $37^{\circ} \mathrm{C}$ for $48 \mathrm{~h}$. Plates were counted and expressed as $\log \mathrm{CFU} / \mathrm{g}$ sample. Psychrotrophic bacteria: Petri dishes containing Standard Agar were used for the PCA count. The dishes were incubated for 10 days at $7^{\circ} \mathrm{C}$ (Collins and Lyne, 1984 ). Total coliforms counts: Most Probable Number (MPN) method is used for the quantitative estimation for coliform were performed according to the techniques recommended by Feng et al. (2002). Salmonella spp: Fish muscle was homogenized with buffered peptone water (Oxoid, CM 509, Hampshire, England). After $18 \mathrm{~h}$ incubation, the samples were inoculated into tubes with tetrathionate broth base (Oxoid, CM0029) with iodine-iodide solution. Samples were incubated for $24 \mathrm{~h}$ in $37^{\circ} \mathrm{C}$, and then aliquots were spread onto plates containing with SS agar (Merck, 1.07667) and incubated again in 37
${ }^{\circ} \mathrm{C}$ for $24 \mathrm{~h}$ (Andrews and Hammack, 2007). Aeromonas spp. were enumerated and isolated by plating on Dextrin-Ampicilin Agar (ampicilin 10 mg.L-1) and incubated at $30{ }^{\circ} \mathrm{C}$ for 48 hours. Colonies were subjected to test of motile, Gram stain and biochemical tests of cytochrome oxidase, D-glucose fermentation, arginine dihydrolase, and ornithine decarboxylase, ONPG, $\mathrm{H}_{2} \mathrm{~S}$ from cysteine, acetoin from glucose, gas from glucose, L-arabinose utilization and fermentation of salicin (FDA, 2001).

\subsection{Sensory analysis}

Sensory evaluation was performed by 15 trained panelists. They were required to evaluate the raw fillets based on the color, flavor, texture (from firm to soft) and overall acceptability using a 7-point hedonic scale. Scores below 4 points were considered unacceptable according to Ruiz-Capillas and Moral (2001).

\subsection{Statistical analysis:}

Triplicate samples $(n=3)$ were analyzed for each property. The results were expressed in terms of mean and Stander Error (SE) of mean. Statistical analysis (ANOVA) was applied to the data followed by Duncan's Multiple Range Test (Duncan, 1955) using SPSS software. Differences between means were determined by the least significant difference test, and significance was defined at $P<0.05$.

\section{RESULTS}

Table 1: The mean values of changes in TVB-N $(\mathrm{mg} / 100 \mathrm{~g})$ values of Tilapia fillets during storage at $2 \mathrm{C}^{\mathrm{o}}$.

\begin{tabular}{ccccc}
\hline \multirow{2}{*}{ Time of storage (days) } & G1 & TVB-N $(\mathrm{mg} / 100 \mathrm{~g})$ \\
& $\mathrm{G} 2$ & $\mathrm{G} 3$ & $\mathrm{G} 4$ \\
\hline 1 & $15.00 \pm 0.2^{\mathrm{Aa}}$ & $14.07 \pm 0.4^{\mathrm{Aa}}$ & $14.07 \pm 0.6^{\mathrm{Aa}}$ & $13.13 \pm 0.5^{\mathrm{Aa}}$ \\
7 & $14.30 \pm 0.3^{\mathrm{Aa}}$ & $12.90 \pm 0.5^{\mathrm{Aa}}$ & $12.27 \pm 0.3^{\mathrm{Aa}}$ & $13.16 \pm 0.7^{\mathrm{Aa}}$ \\
14 & $15.00 \pm 0.5^{\mathrm{Aa}}$ & $14.07 \pm 0.2^{\mathrm{Aa}}$ & $13.37 \pm 0.1^{\mathrm{Aa}}$ & $14.07 \pm 0.3^{\mathrm{Aa}}$ \\
21 & $19.90 \pm 0.7^{\mathrm{Aa}}$ & $15.93 \pm 0.3^{\mathrm{Aa}}$ & $18.97 \pm 0.2^{\mathrm{Aa}}$ & $15.23 \pm 0.5^{\mathrm{Aa}}$ \\
\hline
\end{tabular}

${ }^{\mathrm{AB}}$ Values followed by different capital letter within the same column are significantly different $(P<0.05)$.

ab Values followed by different small letter within the same row are significantly different $(P<0.05)$.

Table 2: The mean values of changes in TBARS values of Tilapia fillets during storage at $2 \mathrm{C}^{\circ}$.

\begin{tabular}{|c|c|c|c|c|}
\hline \multirow{2}{*}{ Time of storage (days) } & \multicolumn{4}{|c|}{ TBA mg Malonaldehyde/Kg } \\
\hline & G1 & G2 & G3 & G4 \\
\hline 1 & $0.79 \pm 0.06^{\mathrm{Aa}}$ & $0.84 \pm 0.10^{\mathrm{Aa}}$ & $0.57 \pm 0.07^{\mathrm{Aa}}$ & $0.04 \pm 0.08^{\mathrm{Aa}}$ \\
\hline 7 & $3.00 \pm 0.04^{\mathrm{Bb}}$ & $1.58 \pm 0.08^{\mathrm{Aa}}$ & $1.36 \pm 0.03^{\mathrm{Aa}}$ & $0.78 \pm 0.05^{\mathrm{Aa}}$ \\
\hline 14 & $6.16 \pm 0.03^{\mathrm{Cc}}$ & $2.38 \pm 0.05^{\mathrm{Bb}}$ & $2.22 \pm 0.08^{\mathrm{Bb}}$ & $0.79 \pm 0.03^{\mathrm{Aa}}$ \\
\hline 21 & $9.23 \pm 0.06^{\mathrm{Dc}}$ & $2.56 \pm 0.03^{\mathrm{Bb}}$ & $8.07 \pm 0.01^{\mathrm{Cc}}$ & $0.98 \pm 0.01^{\mathrm{Aa}}$ \\
\hline
\end{tabular}


Table 3: The mean values of changes in $\mathrm{pH}$ values of Tilapia fillets during storage at $2 \mathrm{C}^{\circ}$ :

\begin{tabular}{ccccc}
\hline \multirow{2}{*}{ Time of storage (days) } & \multicolumn{4}{c}{$\mathrm{pH}$ value } \\
& $\mathrm{G} 1$ & $\mathrm{G} 2$ & $\mathrm{G} 3$ & $\mathrm{G} 4$ \\
\hline 1 & $6.5 \pm 0.02^{\mathrm{Aa}}$ & $6.4 \pm 0.01^{\mathrm{Aa}}$ & $6.2 \pm 0.01^{\mathrm{Aa}}$ & $5.9 \pm 0.04^{\mathrm{Ba}}$ \\
7 & $6.4 \pm 0.01^{\mathrm{Aa}}$ & $6.4 \pm 0.02^{\mathrm{Aa}}$ & $6.1 \pm 0.04^{\mathrm{Ba}}$ & $6.2 \pm 0.01^{\mathrm{Aa}}$ \\
14 & $6.6 \pm 0.03^{\mathrm{Aa}}$ & $6.5 \pm 0.02^{\mathrm{Aa}}$ & $6.2 \pm 0.02^{\mathrm{Ba}}$ & $6.1 \pm 0.01^{\mathrm{Ba}}$ \\
21 & $6.6 \pm 0.01^{\mathrm{Aa}}$ & $6.5 \pm 0.01^{\mathrm{Aa}}$ & $6.3 \pm 0.01^{\mathrm{Ba}}$ & $6.2 \pm 0.02^{\mathrm{Ba}}$ \\
\hline
\end{tabular}

Table 4: Mean scores of sensory characteristics of Tilapia fillets during storage at $2 \mathrm{C}^{\circ}$

\begin{tabular}{|c|c|c|c|c|}
\hline \multirow{2}{*}{ Time of storage (days) } & \multicolumn{4}{|c|}{ Sensory Scores } \\
\hline & G1 & $\mathrm{G} 2$ & G3 & G4 \\
\hline \multicolumn{5}{|l|}{ Color } \\
\hline 1 & $6.60 \pm 0.21^{\mathrm{Aa}}$ & $6.40 \pm 0.22^{\mathrm{Aa}}$ & $6.40 \pm 0.1^{\mathrm{Aa}}$ & $6.30 \pm 0.11^{\mathrm{Aa}}$ \\
\hline 7 & $6.20 \pm 0.13^{\mathrm{Aa}}$ & $6.10 \pm 0.12^{\mathrm{Aa}}$ & $5.70 \pm 0.14^{\mathrm{Bb}}$ & $6.00 \pm 0.16^{\mathrm{Aa}}$ \\
\hline 14 & $4.00 \pm 0.19^{\mathrm{Bb}}$ & $5.50 \pm 0.18^{\mathrm{Ba}}$ & $4.50 \pm 0.21^{\mathrm{Bb}}$ & $5.80 \pm .0 .12^{\mathrm{Ab}}$ \\
\hline 21 & $2.90 \pm 0.26^{\mathrm{Cc}}$ & $3.80 \pm 0.16^{\mathrm{Cb}}$ & $3.9 \pm 0.15^{\mathrm{Cb}}$ & $5.50 \pm .0 .14^{\mathrm{Aa}}$ \\
\hline \multicolumn{5}{|l|}{ Odor } \\
\hline 1 & $6.40 \pm 0.12^{\mathrm{Aa}}$ & $6.60 \pm 0.11^{\mathrm{Aa}}$ & $6.50 \pm 0.15^{\mathrm{Aa}}$ & $6.10 \pm 0.16^{\mathrm{Aa}}$ \\
\hline 7 & $4.80 \pm 0.22^{\mathrm{Bb}}$ & $6.10 \pm 0.13^{\mathrm{Aa}}$ & $5.00 \pm 0.14^{\mathrm{Ab}}$ & $6.00 \pm 0.21^{\mathrm{Aa}}$ \\
\hline 14 & $3.70 \pm 0.24^{\mathrm{Bc}}$ & $5.40 \pm 0.21^{\mathrm{Bb}}$ & $5.10 \pm 0.12^{\mathrm{Bb}}$ & $5.70 \pm 0.14^{\mathrm{Bb}}$ \\
\hline 21 & $2.80 \pm 0.12^{\mathrm{Cd}}$ & $3.90 \pm 0.16^{\mathrm{Cc}}$ & $3.7 \pm 0.11^{\mathrm{Cc}}$ & $5.30 \pm 0.12^{\mathrm{Bb}}$ \\
\hline \multicolumn{5}{|l|}{ Texture } \\
\hline 1 & $6.80 \pm 0.16^{\mathrm{Aa}}$ & $6.70 \pm 0.14^{\mathrm{Aa}}$ & $6.50 \pm 0.11^{\mathrm{Aa}}$ & $6.70 \pm 0.12^{\mathrm{Aa}}$ \\
\hline 7 & $6.20 \pm 0.11^{\mathrm{Aa}}$ & $6.30 \pm 0.12^{\mathrm{Aa}}$ & $6.00 \pm 0.16^{\mathrm{Aa}}$ & $6.60 \pm 0.11^{\mathrm{Aa}}$ \\
\hline 14 & $5.40 \pm 0.13^{\mathrm{Bb}}$ & $6.10 \pm 0.15^{\text {Aa }}$ & $5.50 \pm 0.18^{\mathrm{Bb}}$ & $6.30 \pm 0.21^{\mathrm{Aa}}$ \\
\hline 21 & $4.30 \pm 0.12^{\mathrm{Cc}}$ & $5.30 \pm 0.16^{\mathrm{Bb}}$ & $5.40 \pm 0.21^{\mathrm{Bb}}$ & $6.10 \pm 0.17^{\mathrm{Aa}}$ \\
\hline \multicolumn{5}{|l|}{ Overall Acceptability } \\
\hline 1 & $6.70 \pm 0.11^{\mathrm{Aa}}$ & $6.60 \pm 0.14^{\mathrm{Aa}}$ & $6.20 \pm 0.15^{\mathrm{Aa}}$ & $6.60 \pm 0.13^{\mathrm{Aa}}$ \\
\hline 7 & $5.70 \pm 0.14^{\mathrm{Bb}}$ & $6.20 \pm 0.12^{\mathrm{Aa}}$ & $6.10 \pm 0.22^{\mathrm{Aa}}$ & $6.30 \pm 0.12^{\mathrm{Aa}}$ \\
\hline 14 & $4.10 \pm 0.16^{\mathrm{Cc}}$ & $4.90 \pm 0.13^{\mathrm{Bb}}$ & $5.30 \pm 0.17^{\mathrm{Bb}}$ & $6.10 \pm 0.15^{\mathrm{Aa}}$ \\
\hline 21 & $3.80 \pm 0.16^{\mathrm{Cd}}$ & $4.30 \pm 0.12^{\mathrm{Cb}}$ & $3.20 \pm 0.16^{\mathrm{Cc}}$ & $5.90 \pm 0.12^{\mathrm{Bb}}$ \\
\hline
\end{tabular}

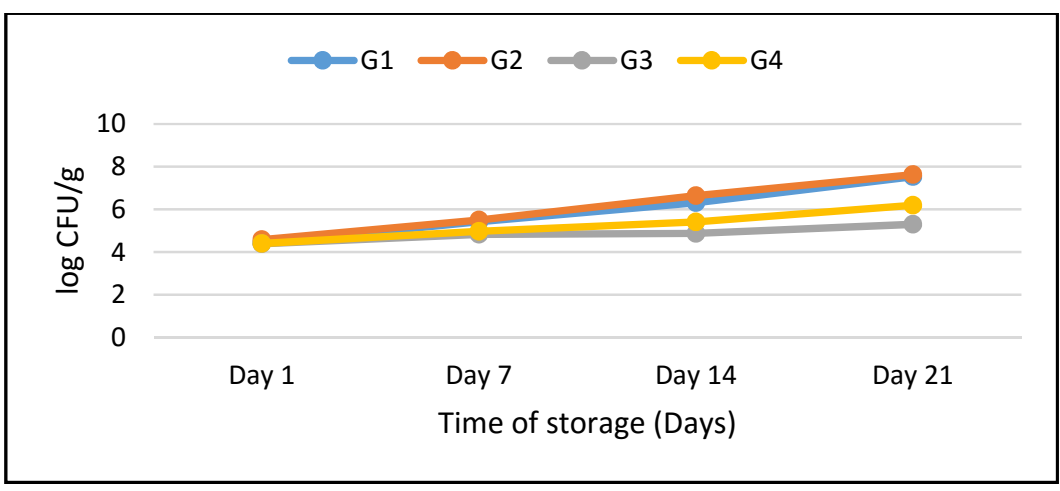

Figure (1): Total viable microbial count in tilapia fillets stored at $2 \mathrm{C}^{\circ}$ 


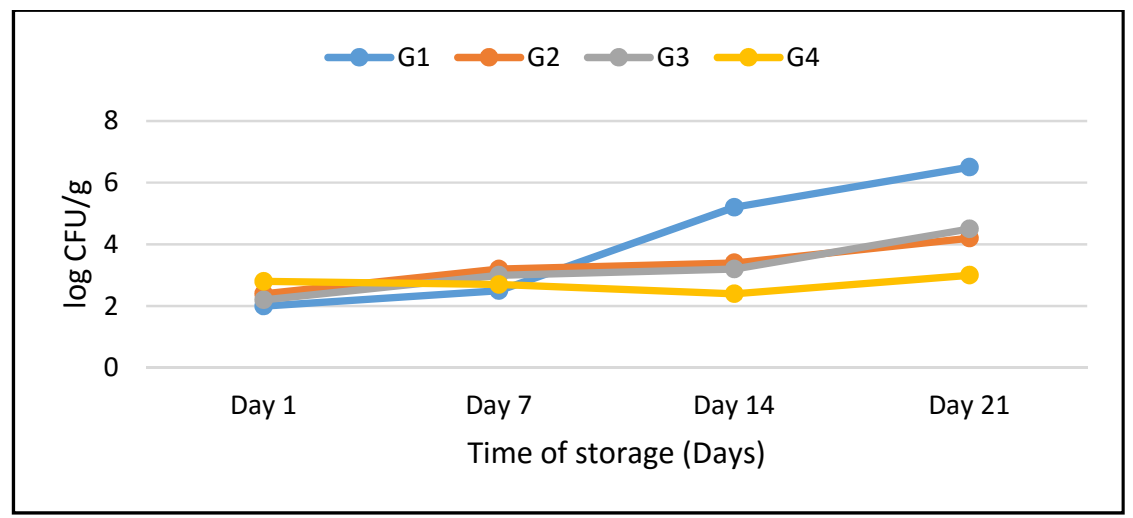

Figure (2): Psychrotrophic bacterial count $(\log \mathrm{CFU} / \mathrm{g})$ in tilapia fillets stored at $2{ }^{\circ} \mathrm{C}$

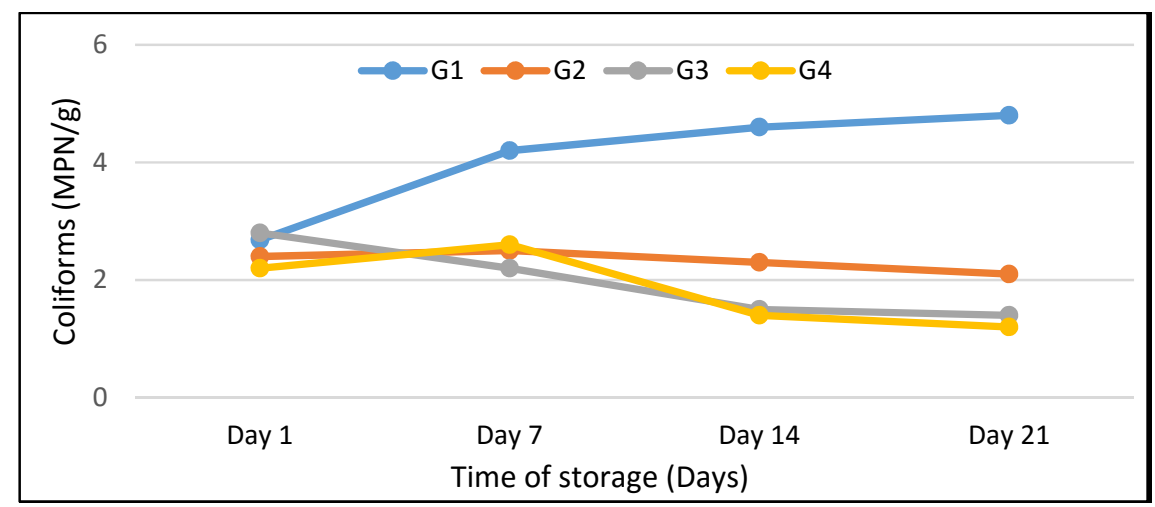

Figure (3): Total coliform counts (MPN/g) in tilapia fillets stored at $2{ }^{\circ} \mathrm{C}$

\section{DISCUSSION}

TVB-N value is a quality index for unprocessed fishery products indicative of fish spoilage because of metabolic activity of fish spoilage bacteria and endogenous enzymes action (Connell, 1990). A level of $35 \mathrm{mg} / 100 \mathrm{~g}$ has been considered as an upper limit above which fishery products are considered unfit for human consumption (Ludorff and Meyer, 1973; Schormüller, 1968).

In our study, the TVB-N values for all the treatments were below the unaccepted limit and they were not significantly $(p>0.05)$ affected by the treatments and storage periods (Table 1). High initial values followed by decreases were observed for some treatments. The average TVB-N value in (G1), (G2), (G3) and (G4) fillet samples were $15.00 \pm 0.2,14.07 \pm 0.4,14.07 \pm 0.6$ and $13.13 \pm 0.5$ $\mathrm{mg} \mathrm{N} / 100 \mathrm{~g}$ on day 1 , respectively. The average TVB-N level in (G1), (G2), (G3) and (G4) fillet samples were $19.90 \pm 0.7,15.93 \pm 0.3,18.97 \pm 0.2$ and15.23 $\pm 0.5 \mathrm{mg} \mathrm{N} / 100 \mathrm{~g}$ on day 21 of storage at $2{ }^{\circ} \mathrm{C}$, respectively. These findings were in agreement with those reported by Dokuzlu (1997), Aksu et al. (1997), Cascado et al. (2005) and Olgunoğlu (2007).
This dynamic change in TVN level could be related to the growth of microorganisms as proliferation of the microflora contributing to spoilage changes as seen by increased TVN level. This correlation is in agreement with the findings of Balamatsia et al. (2007), which firstly reported that trimethylamine (TMA-N) and total volatile nitrogen (TVN) could be employed as potential chemical indicators in monitoring the microbial quality of fresh meat during chill storage under aerobic and modified atmosphere packaging (MAP) conditions. Banks et al. (1980) indicated that the differences in TVB-N amounts must have been caused by a smaller number of bacteria their ability to act on the oxidative desamination of non-protein nitrogen compounds. A second explanation refers to the anaerobic conditions found in the $\mathrm{CO}_{2} \mathrm{MAP}$, as they may inhibit this reaction due to the lack of atmospheric oxygen. Rokka et al. (2004) showed a clear relationship between the microbiological quality of meat (proteinbased) and the total amount of Total Volatile nitrogen (TVN) and biogenic amines.

The TBARS value was widely used for measuring lipid oxidation in fish and fish products (Yanar et al., 2006). Fish lipid typically contained high percentage 
which tended to increase as the storage duration increased.

TVC in $(\mathrm{G} 4)$ was significantly $(p<0.05)$ lower than other groups in each occasion of examination, which indicates the high antimicrobial activities of MAP, associated with $1 \%$ acetic acid. Regarding the upper acceptability limit recommended by Egyptian organization for standardization (EOS) (2005) for total viable count in fresh fish $\left(6 \log _{10}\right.$ $\mathrm{CFU} / \mathrm{g}$ flesh), it could be observed that (G1) exceeded such limit at $9^{\text {th }}$ day of storage, while such limit has not exceeded by treated groups until time of spoilage. Lower TVC of sample kept under MAP indicated that $\mathrm{CO}_{2}$ at a concentration $60 \%$ effectively inhibited the microbial growth. $\mathrm{CO}_{2}$ commonly become more effective as antibacterial agent when its concentration is increased (Farber, 1991). It retards the microbial growth of spoilage bacteria such as Pseudomonas spp. and Shewanella spp. Thus, $\mathrm{CO}_{2}$-enriched atmosphere has been used in the preservation for fresh fishery products. This was probably because $\mathrm{CO}_{2}$ entered into mass action equilibrium for enzymatic decarboxylation, leading to inhibition of the metabolic activity of microbial flora as result of an extension in lag phase and a reduction in logarithmic phase of spoilage bacteria (Lalitha et al., 2005; Masniyom et al., 2011). Our result was in agreement with Özogul et al. (2004) who reported that TVC was retarded when sardine (Sardina pilchardus) were kept in $60 \% \mathrm{CO}_{2}$-enriched atmospheres. It has been reported that $50 \% \mathrm{CO}_{2}$ inhibited the microbial growth in chub mackerel (Scomber colias japonicus) during storage (Stamatis and Arkoudelos, 2007).

Psychrotrophic bacteria are very important among different bacteria causing spoilage, because they are mostly related to the changes in sensory attributes such as odor, texture and flavor and could produce different metabolic compounds such as ketones, aldehydes, volatile sulfides and biogenic amines (Safari and Yosefian, 2006). A proposed limit of psychrotrophic bacteria is $10^{3}$ to $10^{4} \mathrm{cfu} / \mathrm{g}$, which is consistent with other studies (PonsSanchez-Cascado et al., 2006).

Results that obtained in Figure (2) presents the psychrotrophic bacterial count (log CFU/g) during the storage period. The development of psychrotrophic bacteria increased during the storage period, with values above $10^{6} \mathrm{CFU} / \mathrm{g}$ being verified for the control (G1). Although the limits for psychrotrophic bacteria are not within the legislative scope, such high counts for this group of bacteria must contribute to the reduction in product shelf life. The increase in the psychrotrophic bacterial count for the control is also related to the increase in $\mathrm{pH}$, despite the product being sensorially accepted by the tasters, who considered the appearance to be the most important attribute. (G2) and (G3) fillet samples presented a decrease in the bacterial count on the $7^{\text {th }}$ and $13^{\text {th }}$ days of storage, respectively, (G4) fillet samples presenting the lowest count at the end of the storage period. Probably, this fact was a consequence of the high $\mathrm{CO}_{2}$ concentration associated with the use of acetic acid, as both show antimicrobial action.

The values obtained for (G2) and (G4) fillet samples were similar to those found by Randell et al. (1999), when studying salmon fillets stored at $2{ }^{\circ} \mathrm{C}$ under $60 \% \mathrm{CO}_{2} / 40 \% \mathrm{~N}_{2}$ MAP and vacuum packs. Silliker and Wolfe (1980) observed that high $\mathrm{CO}_{2}$ concentrations inhibited the growth of psychrotrophic microorganisms when the fish was stored under low temperature conditions, evidencing that psychrotrophic bacteria are sensitive to $\mathrm{CO}_{2}$. Reddy et al. (1992) and Silva et al. (1993) verified that the lag phase was retarded and growth of such deteriorating bacteria reduced by $\mathrm{CO}_{2}$. Etemadian et al. (2012) reported that tilapia fillets packaged under vacuum packaging reduced the psychrotrophic bacterial count, compared with the samples packed in air.

The changes in total coliform counts (MPN/g) with storage time in all groups were concluded in Figure (3). The National Academy of Science (1985) reported that coliform group of bacteria in fish and fishery products has been considered important in microbiological analysis on account of their significance as indicator organisms for pin pointing the unhygienic conditions during catching, handling, processing and distribution. Total coliform counts in the tilapia fillets during the storage period were not significantly affected $(p>0.05)$ by the treatments and storage period $(<2$ $\left.3.3 \times 10^{1}\right)$. The only treatment promoting the growth of total coliforms was showed in (G1) samples ( 0.3 $\left.-1.0 \times 10^{2}\right)$, while the others presented a decrease in growth, probably due to the combination of the low temperatures and use of acetic acid, as well as a low contamination level in the water.

At day 1 and $3^{\text {rd }}$ day of storage, there was no significant difference in coliforms MPN between groups, while at $6^{\text {th }}$ day of storage, (G1) was significantly higher $(p<0.05)$ than treated groups, as well as at $9^{\text {th }}$ day, (G1) and (G2) samples were significantly higher $(p<0.05)$ than $(\mathrm{G} 3)$ and $(\mathrm{G} 4)$ samples in coliforms MPN. The inhibitory effect of acetic acid against coliform group of bacteria was previously reported by Harpaz et al. (2003); Hernandez et al. (2009) and Mahmoud et al. (2004). 
The presence of Salmonella and Aeromonas spp. was not detected in any of the samples analyzed in the experiment. In the same way, Passy et al. (1983) and Randell et al. (1999) did not detect the presence of such bacteria in fresh water prawns (Macrobrachium rosenbergii), catfish (Ictalurus punctatus) and salmon (Salmo salar) during MAP storage. According to Lioutas (1988), fish from non-polluted waters are free from Salmonella because this bacteria is not naturally found in the fish flora and its presence in fish is mainly due to handling or contact with poorly disinfected surfaces.

There was a significant effect of storage time on the sensory qualities of fish fillets. High scores (>6.60) were given to the color of fillets on day 1 (Table 5). There were no significant differences $(p$ $<0.05)$ for the first 3 days for (G1) samples. From the $7^{\text {th }}$ day, colour score decreased significantly and to the unacceptable levels at the $11^{\text {th }}$ day $(<4.0$ point). As for (G2) and (G4) samples, no significant difference was noticed up to 7 days of storage. Panelists rejected the fillets in terms of color at the $14^{\text {th }}$ day for (G2) and at the $21^{\text {st }}$ day for (G4) samples.

There were no significant changes in terms of odor for (G1) samples for the first 3 days of storage, and for (G2) and (G4) samples up to 7 days. However, when they were stored longer, an odor developed and the scores decreased significantly $(p<0.05)$. The products continued to deteriorate ultimately having what is often described as an intense and putrid odor and this could be noticed on the $11^{\text {th }}$ day for (G1) samples, $14^{\text {th }}$ day for $(\mathrm{G} 2)$ samples, and $21^{\text {st }}$ day for (G4) samples. Very high microbial counts were noticed at the later stage of storage days and these could be due to the production of ammonia compounds from spoilage bacteria, resulting in the unacceptable odor.

Similar trends were also observed in texture and overall acceptability of fish fillets. Higher scores were given to all treatments in the first few days of storage and when stored longer, scores given were subsequently lower. Samples of (G1) showed the most marked changes. Fillets became tenderer, less succulent, less firm, less springy, less fibrous, stale, and dull in appearance and produced unpleasant odor. These changes may have resulted from the effect of increasing $\mathrm{pH}$ on protein structure (Love et al., 1979) or from bacterial proteolysis (Shewan, 1974).

Generally, (G1) fish samples were rejected by sensory evaluation at 7 days of storage, 14 days for (G2) samples, and up to 21 days for (G4) samples.
According to the sensory evaluation results, (G3) fillets samples that underwent pretreatment with acetic acid were considered unsuitable for consumption from the $7^{\text {th }}$ day of storage onwards, receiving scores below five for the attributes color, odor and appearance.

\section{CONCLUSIONS}

As conclusion, a delay in chemical, microbiological and sensorial alterations was observed when acetic acid was combined with MAP. Chemical and microbiological levels were significantly lower when MAP fillets samples had been previously immersed in acetic acid. chemical treatment by immersion in $1 \%$ acetic acid had significantly increased the time of storage as MAP stored samples were rejected due to the development of off-odors. Control samples had a shelf life of 7 days, 18 days for MAP samples, and 21 days for MAP associated with immersion in 1\% acetic acid samples.

\section{REFERENCES}

Aksu, H., Erkan, N., Çolak, H., Varlık, C., Gökoğlu, N., Uğur, M., 1997. Some changes in anchovy marinades during production in different acidsalt concentrations and determination of shelflife. Yüzüncüyıl Univ. Journal of Faculty of Veterinary Medicine 8, 86-90.

Andrews, W.H., Hammack, T.S., 2007. Salmonella," in United States Food and Drug Administration (US FDA) Bacteriological Analytical Manual. United States Food and Drug Administration, Silver Spring, Md, USA.

Ang, C.Y.W., 1988. Comparison of Broiler Tissues for Oxidative Changes after Cooking and Refrigerated Storage. J Food Sci 53, 1072-1075.

Balamatsia, C.C., Patsias, A., Kontominas, M.G., Savvaidis, I.N., 2007. Possible role of volatile amines as quality-indicating metabolites in modified atmosphere-packaged chicken fillets: Correlation with microbiological and sensory attributes. Food Chemistry 104, 1622-1628.

Banks, H., Ranzell, N., Finne, G., 1980. Shelf-life studies on carbon dioxide finfish from the Gulf of Mexico. J Food Sci 45, 157-162.

Cascado, S.P.S., Vidal-Carou, M.C., Font, A.M., Veciana-Nogues, M.T., 2005. Influence of the Freshness Grade of Raw Fish on the Formation of Volatile and Biogenic Amines During the Manufacture and Storage of Vinegar. Marinated Anchovies. Journal of the Science of Agriculture and Food Chemistry 53.

Church, N., 1998. Map fish and crustaceans - sensory enhancement Food Science and Technology Today 12, 73-83. 
Collins, C., Lyne, P., 1984 Microbiological methods, 5 th ed. Microbiological laboratory, British library, Butter Worth, UK.

Connell, J.J., 1990. Methods of assessing and selecting for quality. In: J.J. Connell (Ed.), Control of Fish Quality. Fishing News Boks, Oxford.

Cyprian, O.O., Sveinsdottir, K., Magnusson, H., Martinsdottir, E., 2008. Application of quality index method (QIM) scheme and effects of shorttime temperature abuse in shelf life study of fresh water arctic char (Salvelinus alpinus). Journal of Aquatic Food Product Technology 17, 303-321.

Debevere, J., Boskou, G., 1996. Effect of modified atmosphere packaging on the TVB/TMAproducing microflora of cod fillets. International Journal of Food Microbiology 31, 221-229.

Dokuzlu, C., 1997. Determination of shelf life and the effects of different acid-salt ratio on the microbiological and sensory qualities during the production of marinated anchocy. Journal of Pendik Veterinary Microbiology 28, 81-90.

Duncan, D.R., 1955. Multiple ranges and multiple F test. Biometrics 11, 31-42.

Duun, S.A., Rustad, T., 2008. Quality of super chilled vacuum-packed Atlantic salmon (Salmo salar) fillets stored at -1.4 and $-3.6{ }^{\circ} \mathrm{C}$. In Journal of Food Chemistry 106, 122-131.

Egyptian organization for standardization (EOS), 2005. Standard Specifications for chilled and frozen fish fillets (3494) and (2- 889). Egypt EOS.

Etemadian, Y., Shabanpour, B., Mahoonak, A.S., Shabani, A., 2012. Combination effect of phosphate and vacuum packaging on quality parameters of Rutilus frisii kutum fillets in ice. Food Research International 45, 9-16.

Farber, J.M., 1991. Microbiological aspects of modified-atmosphere packaging technology $-\mathrm{a}$ review. Journal of Food Protection 54, 58-70.

FDA, 2001. Bacteriological Analytical Manual on-line. USA: Center of Food Safety and Applied Nutrition. Food and Drug Administration.

Feng, P., Stephen, D.W., Michael, A.G., 2002. Enumeration of Escherichia coli and the coliform bacteria," inBacteriological Analytical Manual. United States Food and Drug Administration (US FDA).

Fu, B., Labuza, T.P., 1993. Shelf life prediction: theory and application. Food Control 4.

Gram, L., Dalgaard, P., 2002. Fish spoilage bacteria problems and solutions. Current Opinion in Biotechnology 13, 262-266.

Gram, L., Wedell-Neergaard, C., Huss, H.H., 1990. The bacteriology of fresh and spoiling Lake Victoria Nile perch (Lates niloticus). International Journal of Food Microbiology 10, 303-316.

Harpaz, S., Glatman, L., Drabkin, V., Gelman, A., 2003. Effects of herbal essential oils used to extend the shelf-life of freshwater-reared Asian sea bass fish (Lates calcarifer). J Food Prot. 66, 410e417.

Hernandez, M.D., Lopez, M.B., Alvarez, A., Ferrandini, E., Garcia Garcia, B., Garrido, M.D., 2009. sensory, physical, chemical and microbiological changes in aquacultured meagre (Argyrosomus regius) fillets during ice storage. Food Chem 114.

Huss, H.H., 1994. Assurance of seafood quality. [Electronic version] Rome. In Fisheries Technical Paper no. 334.

Huss, H.H., 1995. Quality and quality changes in fresh fish. FAO Fisheries Technical Paper 348. FAO. Rome. Italy.

ICMS, 1986. Sampling plans for fish and shellfish. In: ICMSF, microorganisms in foods: sampling for microbiological analysis. Principles and scientific applications 2nd ed. University of Toronto Press, Toronto, Buffalo, London.

Lalitha, K.V., Sonaji, E.S., Manji, S., Jose, L., Gopal, T.K.S., Ravisankar, C.N., 2005. Microbiological and biochemical changes in pearl spot (Etroplus suratensis Bloch) stored under modified atmospheres. Journal of Applied Microbiology 99, 1222-1228.

Li, T.T., Hu, W.Z., Li, J.R., Zhang, X.G., Zhu, J.L., Li, X.P., 2012. Coating effects of tea polyphenol and rosemary extract combined with chitosan on the storage quality of large yellow croaker (Pseudosciaena crocea). Food Control 25, 101106.

Lim, P.Y., 1987. Measurement of pH. In: Laboratory manual on analytical methods and procedures for fish and fish products (Hasegawa, H., Ed.). Singapore: Marine Fisheries Development Southeast Asian Fisheries Development Center, A3.1-A3.2.

Lingham, T., Besong, S., Ozbay, G., Jung-Lim, L., 2012. Antimicrobial Activity of Vinegar on Bacterial Species Isolated from Retail and Local Channel Catfish (Ictalurus punctatus). J Food Process Technol S11-001.

Lioutas, T.S., 1988. Challenges of controlled and modified atmosphere packaging: a food company's perspective. Food Technology 42, 78-86.

Love, R.M., Ratkowsky, D.A., Lowry, R.K., Olley, J., 1979. Structure and proteins of fish and shellfish. Part I. Proc. Torry Research Station Jubilee Conference. Theme: Advances in fish sciences and technology, Farnham, London: Fishing News Books Ltd.

Ludorff, W., Meyer, V., 1973. Fische und fischerzeugnisse. Paul Parey Verlag, HamburgBerlin 309.

Lund, B.M., Baird-Parker, A.C., Gould, G.W., 2000. The microbiological safety and quality of foods. Aspen Publishers, Inc, Gaithersburg, Maryland, USA.

Luten, J.B., Martinsdóttir, E., 1997. QIM: a European tool for fish freshness evaluation in the fishery chain Olasfdóttir, G., Luten, J., Dalgaard, P., Careche, M.,.

Mahmoud, B.S.M., Yamazaki, K., Miyashita, K., Shik, S.I., Dong-Suk, C., Suzuki, T., 2004. Bacterial microflora of carp (Cyprinus carpio) and its 
shelf-life extension by essential oil compounds. Food Microbiol 21, 657-666.

Marel, G.M., Logtestein, J.G., Mossel, D.A.A., 1988. Bacteriological quality of broiler carcasses as affected by in-plant lactic acid decontamination. International Journal of Food Microbiology 6, 31-42.

Martinsdóttir, E., Sveinsdottir, K., Luten, J.B., SchelvisSmit, R., Hyldig, G., 2001. Sensory evaluation of fish freshness. In Reference manual for the fish sector. QIM Eurofish 1-50.

Masniyom, P., Benjama, O., Maneesri, J., 2011. Extending the shelf-life of refrigerated green mussel (Perna viridis) under modified atmosphere packaging. Songklanakarin Journal of Science and Technology 33, 171-179.

Maturin, L.J., Peeler, J.T., 2001. Aerobic plate count," in Bacteriological Analytical Manual, chapter 3. United States Food and Drug Administration (US FDA).

National Academy of Science, 1985. An evaluation of the role of microbiological criteria for foods and food ingredients. National Academy Press, Washington, D C, USA.

Olgunoğlu, I.A. 2007. Sensory, chemical and microbiological changes of marinated anchovy (Engraulis engrasicholus L.1758). PhD, University of Çukurova.

Özogul, F., Polat, A., Özogul, Y., 2004. The effects of modified atmosphere packaging and vacuum packaging on chemical, sensory and microbiological changes of sardines (Sardina pilchardus). Food Chem 85, 49-57.

Parallel Food Testing in the European Union, 1995. Fish. International Consumers Research \& Testing Limited, London, UK.

Pardi, M.C., Santos, I.F., Souza, E.R., Pardi, H.S., 1994. Ciência, higiene e tecnologia da carne: tecnologia da carne e subprodutos. Goiânia: Cegraf/UFG, 638-675.

Parry, R.T., 1993. Principle and application of modified atmosphere packaging of food. Blackie Academic and Professional Glasgow.

Passy, N., Mannheim, C.H., Cohen, D., 1983. Effect of modified atmosphere and pretreatments on quality of chilled fresh water prawns (Macrobrachium rosenbergii) Lebensmittel Wissenschaft und - Technologie 16, 224-229.

Pons-Sanchez-Cascado, S., Vidal-Carou, M.C., Nunes, M.L., Veciana-Nogues, M.T., 2006. Sensory analysis to assess the freshness of Mediterranean anchovies (Engraulis encrasicholus) stored in ice. Food Control 17, 564-569.

Randell, K.H., T.; , Skyttã, E., Sivertsvik, M., Bergslien, H., Ahvenainen, R., 1999. Quality of filleted salmon in various retail packages. Journal of Food Quality 22, 485-497.

Reddy, N.R., Armstrong, D.J., Rhodehamel, E.J., Kautter, D.A., 1992. Shelf-Life Extension and Safety Concerns About Fresh Fishery Products Packaged under Modified Atmospheres - a Review. Journal of Food Safety 12, 87-118.
Reddy, N.R., Schreider, C.L., Buzard, K.S., Skinner, G.E., Armstrong, D.J., 1994. Shelf life of fresh tilapia fillets packaged in high barrier film with modified atmospheres. J Food Sci 59, 260-264.

Reddy, N.R., Villanueva, M., Kautter, D.A., 1995. Shelf life of modified-atmosphere-packaged fresh tilapia fillets stored under refrigeration and temperature-abuse conditions. Journal of Food Protection 58, 908-914.

Rokka, M., Eerola, S., Smolander, M., Alakomi, H.L., Ahvenainen, R., 2004. Monitoring of the quality of modified atmosphere packaged broiler chicken cuts stored at different temperature conditions: B. Biogenic amines as qualityindicating metabolites. Food Control 15, 601607.

Ross, P.M., 2000. The influence of exposure to carbon monoxide on the quality attributes for yellow fin tuna muscle. Journal of Food Processing and Preservation 32, 729-739.

Ruiz-Capillas, C., Moral, A., 2001. Correlation between biochemical and sensory quality indices in hake stored in ice. Food Res. Int. 34, 441-447.

Safari, R., Yosefian, M., 2006. Changes in TVN (Total Volatile Nitrogen) and psycrotrophic bacteria in Persian sturgeon Caviar (Acipenser persicus) during processing and cold storage. Journal of Applied Ichthyology 22, 416-418.

Sallam, K.I., Ahmed, A.M., Elgazzar, M.M., Eldaly, E.A., 2007. Chemical quality and sensory attributes of marinated Pacific saury (Cololabis saira) during vacuum-packaged storage at $4^{\circ} \mathrm{C}$. Food Chem 102, 1061-1070.

Schmedes, A., Holmer, G., 1989. A new thiobarbituric acid (TBA) method for determination of free malonaldehyde (MDA) and hydroperoxides selectivity as a measure of lipid peroxidation Journal of American Oil Chemistry Society 66, 813-817.

Schormüller, J., 1968. Handbuch der Lebensmittel Chemie. Band III/2 Teil. Tierische Lebensmittel Eier, Fleisch, Buttermilch. Springer Verlag, Berlin, Heidelberg, New York 1482-1537.

Shewan, J.M., 1974. The biodeterioteration of certain proteinaceous foodstuffs at chill temperatures. In: Industrial Aspects of Biochemistry. NorthHolland Pub. Co, Amsterdam: Federation of European Biochemical Societies.

Siah, W.M., Mohd Ariff, W., 2002. Modified atmosphere storage of barramundi (Lates calcarifer) fillets. J. Trop. Agric and Fd. Sc. 30, 201-207.

Silliker, J.H., Wolfe, S.K., 1980. Microbiological safety considerations in controlled-atmosphere storage of meats. Food Technology 34, 59-63.

Silva, J.L., Harkness, E., White, T.D., 1993. Residual Effect of $\mathrm{Co} 2$ on Bacterial Counts and Surface $\mathrm{Ph}$ of Channel Catfish. Journal of Food Protection 56, 1051-1053.

Simpson, R., Almonacid, S., Acevedo, C., Cortes, C., 2003. Mathematical model to predict effect of temperature abuse in MAP systems applied to 
Pacific Hake (Merluccius australis) Journal of Food Engineering 26, 413-434.

Sivertsvik, M., Jeksrud, W.K., Rosnes, J.T., 2002. A review of modified atmosphere packaging of fish and fishery products - significance of microbial growth, activities and safety. Int J Food Sci Tech 37, 107-127.

Stamatis, N., Arkoudelos, J., 2007. Quality assessment of Scomber colias japonicus under modified atmosphere and vacuum packaging. Food Control 18, 292-300.

Sveinsdottir, K., Martinsdottir, E., Hyldig, G., Sigurgisladottir, S., 2010. Sensory Characteristics of Different Cod Products. J Sens Stud 25, 294-314.
Tarladgis, B.G., Watts, B.M., Younathan, M.T., 1960. A distillation method for the quantitative determination of malondialdehyde in rancid foods The Journal of the American Oil Chemists' Society 37, 44-48.

Yanar, Y., Celik, M., Akamca, E., 2006. Effects of brine concentration on shelf-life of hot-smoked tilapia (Oreochromis niloticus) stored at $4{ }^{\circ} \mathrm{C}$. Food Chem 97, 244-247.

Zambuchini, B., Fiorini, D., Verdenelli, M.C., Orpianesi, C., Ballini, R., 2008. Inhibition of microbiological activity during sole (Solea solea L.) chilled storage by applying ellagic and ascorbic acids. Lwt-Food Sci Technol 41, 17331738 . 